\title{
Somewhere in Europe (1947): Locating Hungary within a shifting geopolitical 12012 landscape distribute
}

\section{ABSTRACT}

Somewhere in Europe/Valahol Európában (Radványi, 1947) was one of the first films made in Hungary after 1945. Financed by the Hungarian Communist Party $(M K P)$, it loudly proclaimed a broad European pertinence in an effort to privilege the universal narrative of childhoods disrupted by the war over narrowly national political concerns. The film's story of a gang of half-starved children battling for survival in a bombed-out Central European landscape places it squarely within a transnational post-war film-making tradition. Similarities with both Italian neorealism and Soviet socialist realist cinema indicate a shared European experience of the war, but is also attributable to the international training and experience of the film's personnel. The director Radványi had worked in the Italian industry, while the scriptwriter was the well-known film theorist Béla Balázs, who had worked in Weimar Germany and Soviet Russia. This article argues that in spite of its ostensible commitment to a communist and humanist ideology, the film gives an insight into the Hungarian national obsession with territorial integrity. Hungary's participation in World War II on the side of the Axis, and its position as a defeated nation under Allied occupation, are seen to complicate the film text. This article contends that in spite its transnational flavour, the film's focus on lost children wandering

\section{KEYWORDS}

Hungary national identity transnational cinema post-war cinema soviet montage neorealism Béla Balázs 
1. All translations by the author unless otherwise stated.

2. Slovakia today has a Hungarian minority amounting to $9.7 \%$ of its overall population of 5.5 million. In Romania, Hungarians make up $6.6 \%$ of the overall population of just under 22 million. In Serbia, Hungarians account for $3.9 \%$ of a total of 7.2 million. (Statistics from the CIA World Factbook https:// www.cia.gov/library/ publications/the-world factbook/index.html, accessed 7 March 2012.) a borderless Europe suggests a preoccupation with the country's uncertain position within a shifting geopolitical landscape. In turn, the film's official reading by Nemeskürty shows an eagerness to accept the film's representation of Hungary as a blameless victim of the war, and gives evidence of a need to insert a (false) break between the country's wartime past as a member of the Axis, and the country's 1968 present as a member of the Communist world order.

\section{INTRODUCTION}

Enter into conversation with a Hungarian, and it will not be long before they will mention someone who you may not have realized was Hungarian. I am conscious of often making this remark myself, before following it up by saying, for instance, 'Johnny Weissmüller; He was Hungarian'. This is part of a national obsession with Hungary's impact on global culture. We may be a small country, but we punch above our weight, we often say. This boastfulness masks an insecurity about the country's importance. I call it an extroverted introspection later in this article, and seek to contextualize it by explaining its roots in the crisis of national identity brought about by the upheavals Hungary suffered and caused in the first half of the twentieth century. In order to do so, I will examine a film, Somewhere in Europe/Valahol Európában, scripted by the theorist Béla Balázs and directed by Géza Radványi in 1947 as a significant milestone on - to use the film's rather curious phrase - 'the roads of historical times'. ${ }^{1}$

After the end of World War I, the victorious Allies redrew the borders of the Austro-Hungarian Empire. Signed in 1920, the Trianon Treaty imposed severe territorial losses on Hungary. Since then, Hungary's national self-image has been characterized by an irrevocable split with the country's actual geography. The country as envisaged in the public imagination continues to span the entire Carpathian Basin, from the foot of the Alps to the peaks of the Carpathian. In 1990, József Antall, head of the first freely elected Government after the fall of Communism, declared himself the Prime Minister of fifteen million Hungarians in a country with a population of ten million. The declaration delighted many in the country where the Trianon Treaty had been a taboo topic since the end of World War II, but sent shockwaves through neighbouring countries with large Hungarian minority populations. ${ }^{2}$ This issue remains extremely divisive, not only across the region, but also within the country. Accession to the European Union, with the removal of physical borders between Hungary, Austria, Slovakia and Romania, if anything, caused further instability in Hungary's national self-image, and has seen a dramatic rise in support for radical and extremist nationalist political formations.

In order to show the profound impact of the traumatic redrawing of the nation's borders I shall focus on the emblematic film Somewhere in Europe, one of only a handful of films to have been produced in Hungary in the immediate aftermath of World War II. Somewhere in Europe is a tragic, but uplifting tale of wartime suffering and post-war promise, and its makers, as we shall see, had no revisionist agenda. It was filmed and released at a time when any possibility of a favourable resolution to Hungary's territorial grievances went up in smoke after the country's role as one of the aggressors in the recent war, and its re-occupation with Hitler's permission in the 1930s of its former territories in Romania and what was then Czechoslovakia. Nonetheless, as I go on to show, the film is clearly concerned with the issue of Hungary's territorial integrity.
1.

2.

3.

4.

5.

6.

7.

8.

9.

10.

11.

12

13.

14.

15.

16.

17.

18.

19.

20.

21.

22.

23.

24.

25.

26.

27.

28.

29.

30.

31.

32.

33.

34.

35.

36.

37.

38.

39.

40.

41.

42.

43.

44.

45.

46.

47.

48.

49.

50.

51.

52. 
Somewhere in Europe heralded a seemingly sharp break with the country's wartime tradition of film-making based largely on the German Heimat film. Its story of a gang of half-starved semi-feral children battling for survival yet retaining their humanity amid the ruins of a Europe devastated by the war makes it part of a post-war trend of films that resonated with a broad audience. Loudly proclaiming its pan-European relevance in its title, Somewhere in Europe aimed to send a profoundly humanist message to the traumatized Central European nations along the Danube. This article seeks to explore the film's articulation of a Hungarian identity within a narrative ostensibly concerned with a pan-European identity.

As I shall argue, the film's European credentials are undermined by its specifically Hungarian concerns with the nation's geographical, political and cultural position within the broader European community. The paradoxical national self-image that emerges (of being inside yet in opposition to Europe), is one that continues to characterize Hungary and can be seen to complicate Hungary's current position within the European community. For this reason, it is particularly timely to revisit Somewhere in Europe, a film that has attracted relatively little critical attention in the English-speaking academic world. For instance, in his Hungarian Cinema (2004), Cunningham names his chapter on the post-war era 'Somewhere in Europe: Reconstruction and Stalinism' (2004: 61-79), but devotes little space to the film, which he mentions in passing as having been a Hungarian Communist party MKP-financed project (2004: 64). This detail in itself throws up the question: to what extent is the film ideologically beneficial from the point of view of the strategic goals of the MKP at this time? This article will return to this issue, and attempt to explore the slippage between the film's style and story, as well as the MKP's ideology. Kenez, whose Hungary from the Nazis to the Soviets is a key text in

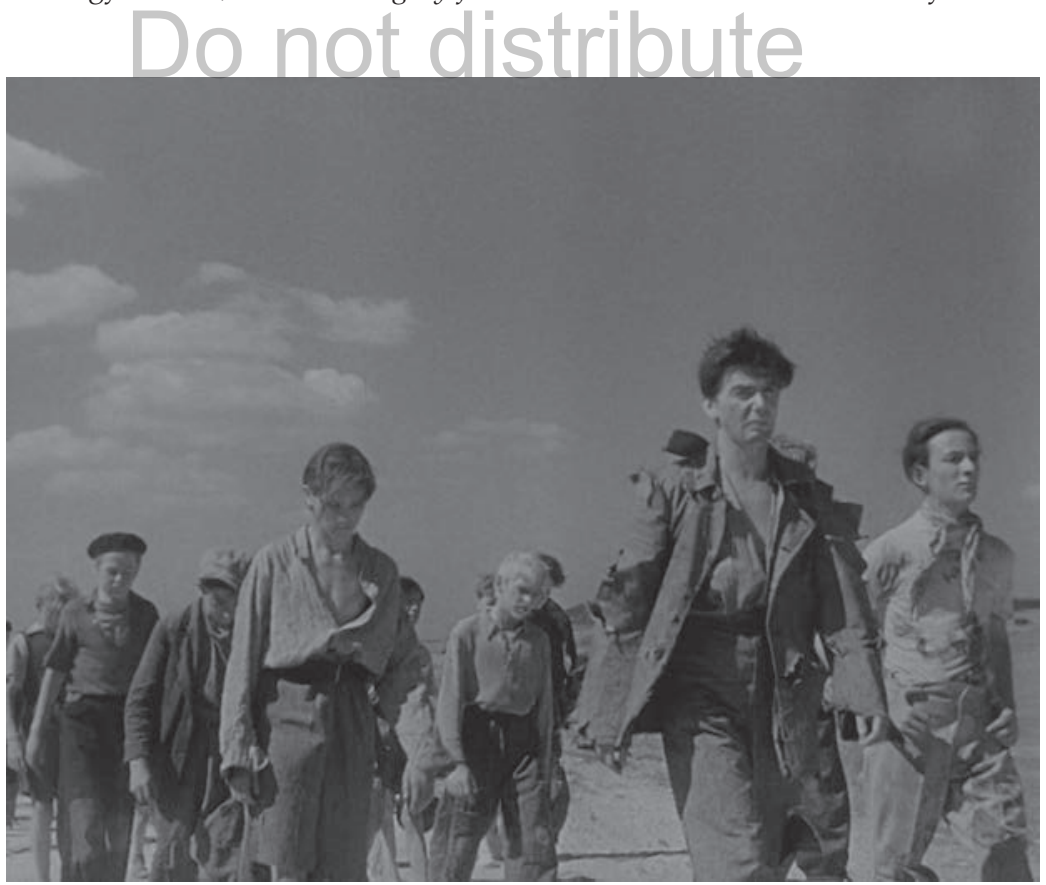

Figure 1: The gang of orphans led by Hosszú (Miklós Gábor, second from right). 
3. Kenez considers the proper term for the Red Army's operation in Hungary. For many Hungarians, it remains distasteful to call it Liberation, when it resulted in over 40 years of Soviet oppression. Yet many feel that to question whether it was a liberation is to express nostalgia for wartime Hungary, the Holocaust and the Hungarian Nazi party, the Arrow Cross. Kenez suggests a complex argument that eschews any possibility of approval of either ideology: although the Red Army expelled the Nazis from Hungary, thereby liberating the country, this was effectively a conquest by a hostile occupying army (2006: 38-45) the context of this article, mentions Somewhere in Europe briefly and praises it with obvious fondness as one of the best Hungarian films (2006: 245-46).

The film has recently received some academic attention, however, although interestingly the film's claim to pan-European relevance remains unquestioned. Parvulescu has recently published an article entirely devoted to the film. In 'The continent in ruins and its redeeming orphans' (2012), Parvulescu argues that the film 'uses the figure of the orphan to articulate a vision of the political future of post-war Europe' (2012: 55). He suggests that the film is best understood as a Marxist text that goes against Stalinist Communism as well as the style of socialist realism (Parvulescu 2012: 55-56), and constitutes a transitional work that can be best understood as a link between the prewar tradition and the post-war future of the Hungarian industry (Parvulescu 2012: 72). His reading is compelling, but it is largely in line with the official analysis of the film, most clearly set down in Nemeskürty (1968: 139-45). Both Parvulescu and Nemeskürty suggest that Somewhere in Europe is a film of broad European pertinence that also ushers in a new era in Hungarian film at the same time as picking up the threads of a pre-war film-making tradition. Given this film's generally acknowledged significance, its long unchallenged official reading, which is coupled with a lack of serious academic attention, and given its reflection of Hungary's immediate historical and political context, its reassessment is long overdue.

This reassessment will begin with a short and by no means exhaustive account of Hungary's history from the Versailles Treaty to the beginning of Communist one-party rule in 1948, after which I will sketch the background of Somewhere in Europe. I will explain its roots in the European film-making tradition, specifically its debt to Italian neorealism, Eisensteinian montage and the Soviet socialist realist school. I offer a detailed analysis of the film's opening sequence to show its remarkable combination of a Soviet montage approach with a neorealist concern with children, and their significance as a focal point of national hopes and anxieties surrounding an uncertain future. I argue that by virtue of its internationally trained crew, its firm focus on the broadly European (indeed, universal) issue of the fate of the weak in the post-war moment, and due to its loudly proclaimed commitment to humanist values that transcend national borders, Somewhere in Europe is a film best understood within the framework of a transnational cinema approach. Having established the film's relevance to issues of global-local intersections and to literal and metaphorical border-crossings, I set out the case for a national cinema approach. Consequently the second half of this article is used to argue that the film's primary concerns are with national (re)definition, and to explore the film's specifically Hungarian obsessions with a national identity defined as much as destabilized by its fluidity, the result of a series of wars and occupations, from the Ottoman conquest to the invasion by Nazi Germany and finally the expulsion of the German forces by the Soviet Red Army. ${ }^{3}$

\section{CONTEXTS}

In order to show how the film reflects on the issues flagged up above, it is necessary to briefly outline Hungary's role in the major upheavals of the first half of the twentieth century. Hungary came out badly after World War II. A loser at the end of World War I, Hungary saw its territory reduced by twothirds under the provisions of the Treaty of Trianon of 1920, the part of the Versailles Treaty that settled the terms of surrender of the Austro-Hungarian
1.

2.

3.

4.

5.

6.

7.

8.

9.

10.

11.

12.

13.

14.

15.

16.

17.

18.

19.

20.

21.

22.

23.

24.

25.

26.

27.

28.

29.

30.

31.

32.

33.

34.

35.

36.

37.

38.

39.

40.

41.

42.

43.

44.

45.

46.

47.

48.

49.

50.

51.

52. 
Empire. Transylvania was annexed to Romania. Large regions were incorporated into the newly formed Czechoslovakia, and several counties in the South were incorporated into Yugoslavia. Major commercial and industrial centres, as well as important railway infrastructures were cut off when the borders were redrawn. In response to the demand for scapegoats for the national trauma that came to be known simply as 'Trianon', anti-Semitism bubbled to the surface in a country where the Jewish community had enjoyed rights and prosperity virtually unparalleled in Europe. Hungary, although still a destination for Jews escaping pogroms and persecution in Poland and Slovakia (Braham 2000: 25), slowly drifted towards institutional anti-Semitism and a national identity politics based in the denial of the rights of the country's substantial and largely assimilated, acculturated and integrated Jewish communities. ${ }^{4}$ Indeed, such was this drift, Hungary was the first country in the inter-war period to adopt radical anti-Jewish legislation. The 1923 Numerus Clausus Act limited the number of Jewish students in higher education to no more than the proportion of Jews within the overall population. Although the act was allowed to lapse after a few years (Braham 2000: 22), it heralded the start of the process of the 'isolation, expropriation and ghettoization' of the Jews (Braham 2001: 7), which culminated in the Holocaust.

A Communist uprising in 1919 had seen the brief rise to power of Béla Kun at the head of the Tanácsköztársaság, the Hungarian Soviet Republic. His Government was toppled after barely more than 100 days as a result of Romanian armed intervention. In 1920 Miklós Horthy, a naval commander in the Austro-Hungarian forces in World War I, marched into Budapest and assumed power as the self-styled Regent of the Kingdom of Hungary. ${ }^{5}$ He would govern Hungary for over twenty years. He oversaw a period of relative prosperity, but failed to resolve deeply ingrained inequalities. Horthy refused to implement sorely needed but painful land reforms, which would have benefitted the poor peasantry, but would have hurt the landed aristocracy who wielded much of the country's political power. Ultimately, Horthy led Hungary into a disastrous alliance with Nazi Germany and participation in World War II in the Axis in the hope of recapturing the territories lost in the Trianon Treaty. In 1944 Horthy sought to extricate Hungary from its commitments, once it became clear that the alliance with Nazi Germany would not only fail to secure the restoration of the pre-Trianon national borders, but would also end in the defeat of the Axis. The attempt to emulate Italy's surrender to the West was a complete failure. The uncompromisingly antiCommunist Horthy's refusal to agree to the Allies' terms (of declaring war on Germany and attacking the German troops on the Hungarian border, leaving the country's eastern borders unprotected from a possible Soviet invasion) sealed the country's fate. Germany did not watch idly as Horthy procrastinated, and the Wermacht marched into the country in March 1944. This also signalled the beginning of the deportation and mass-murder of Hungary's Jewish community, with the full complicity of the Hungarian political class, and much of the population (see Braham 2000, 2001: 3-24). Although the Jewish community in the capital, Budapest, had the financial means to stave off deportations, it too suffered heavy losses after the Hungarian Nazi party, the Arrow Cross, and its fanatical leader Ferenc Szálasi took power in October, 1944. The Jewish communities elsewhere in the country were annihilated completely, and within just four months from the beginning of deportations the country, with the exception of Budapest, was Judenrein, or free of Jews in the Nazis' chilling term (Braham 2001: 14).

\footnotetext{
4. This was, of course, far from being a homogenous Jewish community. For information on the heterogeneity of Hungary's Jewish population of the interwar period, see Braham (2000).

5. Bizarrely, this was a kingless Kingdom (see Kenez 2006: 7, 104).
} 
6. For a detailed account of the transition to multiparty rule, and the rigged elections that saw the beginning of Communist oneparty rule, see Kenez (2006: 259-88)

7. Mátyás Rákosi was the leader of the MKP in exile. He became General Secretary of the MKP and led Hungary between 1948 and 1956.
Even before the Red Army laid siege to Budapest, the political parties, some newly formed, others reformed, began work on establishing a political structure to deal with the most pressing tasks. ${ }^{6}$ The party best situated to press its advantage was the MKP, whose main figures had spent the war years in the relative comfort of Moscow (compared to those Hungarian opposition politicians who had spent the war in hiding, in prison or concentration camps). Not only were they primed for the task of establishing Communist rule in Hungary, they also enjoyed the support of the Red Army, the Allied Control Commission (ACC) and its Russian head Marshal Voroshilov (Kenez 2006: 61-66). The Communists were conscious of the need to raise support in a country that remained fundamentally conservative and generally hostile to Communist political ambitions, despite the disastrous outcome of twenty years of uninterrupted Conservative rule. In order to drum up support, the MKP made an explicit commitment to land reform, keeping quiet, for now, its long-term goal of full nationalization and collectivization. Showing both the population's continued (and frankly shameful) distrust of the Jews, and the Communists' all-conquering ambition for power, Kenez cites internal MKP memoranda (Kenez 2006: 98) to show the deliberate strategy of keeping activists with recognizably Jewish faces away from those the party sought to win for their cause. Giving further evidence of the cynical pragmatism of the Communists, he cites MKP general secretary Rákosi's ${ }^{7}$ remark that it was easy and therefore imperative to win former Arrow Cross members to the Communist cause (Kenez 2006: 47). This shows the party's belief in pursuing the politically expedient strategy, even when in conflict with the party's official ideology. This" is significant because, as I will argue, a similar conflict can be noted in Somewhere in Europe. In what follows, I intend to show that the explicit political commitment to humanist values and the principles of a socialist revolutionary consciousnesss, as articulated in official Soviet cultural directives, can be apprehended in the film alongside a familiar discourse surrounding the loss of identity precipitated by geographical dislocation. The reassertion of identity, a central concern of the film, is imagined through a reconnection with the past and past glories in a withdrawal from the urban wasteland to a rural idyll that goes against both neorealism's focus on new beginnings amid the urban devastation, and Soviet socialist realism's focus on urban rejuvenation and its counterpart, rural mechanization and collectivization.

\section{THE FILM}

Somewhere in Europe was one of the first films made in Hungary after the war. The film was financed by the MKP. As Nemeskürty writes in his Word and Image (the state-sanctioned history of Hungarian cinema, first published in English in 1968), the film studios had been nominally nationalized, but production in this initial post-war period remained in private hands (1968: 139). Private production companies made the few films of this period, with each project receiving party financing depending on the project, the ideological leanings of those involved, and the merits perceived by the given political party. It is easy to understand the MKP's approval of a film, which focused on a nameless child in the aftermath of the war, and its impact on the peoples of Central Europe, and painstakingly avoided any explicit mention of narrow national concerns.

'Where is the sweeping impetus of starting something new, of wanting something different? Where are the problems which engrossed so many
1.

2.

3.

4.

5.

6.

7.

8.

9.

10.

11.

12.

13.

14.

15.

16.

17.

18.

19.

20.

21.

22.

23.

24.

25.

26.

27.

28.

29.

30.

31.

32.

33.

34.

35.

36.

37.

38.

39.

40.

41.

42.

43.

44.

45.

46.

47.

48.

49.

50.

51.

52. 
people after 1945, and were taken up one after the other, for instance, by Italian neorealist films?' (1968: 140) Nemeskürty asks, despairing of the unimaginative output of the period. He writes: 'In these three years [1945-47] only István Szőts and Géza Radványi created work of lasting merit, work that was in inner harmony with the post-liberation period' (Nemeskürty 1968: 143). Radványi, director of Somewhere in Europe, is then the maker of a film of lasting merit, a film that faithfully reflected its period and context and the concerns of post-war Hungary, according to Nemeskürty. I will return to this remark, and seek to account for Nemeskürty's insistence that Radványi and his film are not located in the wartime film-making tradition, despite plenty of evidence to the contrary, as I near the conclusion of this article.

Nemeskürty points out the few promising developments in the immediate post-war period:

Béla Balázs came home, founded a journal, gave lectures, and began to teach the new public how to look at films, and new creative teams how to make films, training the first students of film production after 1945, who were to direct their first films in the 'fifties'.

(Nemeskürty 1968: 139)

Balázs was the author of the seminal Der Sichtbare Mensch/The Visible Man (1924), inspired by his exposure to the German expressionist canon during his exile in Weimar Germany after the failure of the Hungarian Soviet Republic (Balázs 1970: 3). Here, he made forays into film-making and wrote screenplays for Pabst and Riefenstahl. He fled Germany when Hitler camerto power, and he became a member of the group of exiled Hungarian Communists living in the Soviet Union. Inspired by Nikolai Ekk's 1931 film, Road to Life (Nemeskürty 1968: 144), Balázs wrote a screenplay of vagrant children facing hardships in the devastated landscape of post-war Europe: Thanks largely to Balázs, but also to director Radványi who had spent much of the war working in the Italian film industry (Nemeskürty 1968: 145), ${ }^{8}$ the burgeoning Italian neorealist movement, the Soviet montage school and German expressionism can all be apprehended in the finished film.

Somewhere in Europe, is in many ways a truly transnational film as much in terms of the message it seeks to put out, as in terms of the styles it invokes. Its cast and crew may have been largely Hungarian, but the inspiration, the creative artists' education and experience, and the film's scope and setting ensure a broad inter- or indeed transnational appeal and pertinence. For this reason, a transnational cinema approach to the film would seem the most appropriate. The film deals with the legacy of a shared trauma that afflicted the whole continent (and, indeed, the globe), and is set in a loosely defined European location. It traces the intersection of global conflict and local experience through the figure of the child, tying the film to a transnational film-making tradition born out of the shared experience of the war. Shifting geopolitical borders can be seen to act on the fate of the children in the film: with the borders shifting around them, they are forced to cross other, metaphorical borders. They step beyond the law in order to satisfy the most elemental human urge: hunger.

And yet, Nemeskürty's judgement is that the film is of its time and place, even if he cites anecdotal criticisms of the film's failure to situate the action. In his words, the film was made by 'the best men of Hungarian films' (Nemeskürty 1968: 145) and is part of a trend of 'starting something new, of wanting something different' (Nemeskürty 1968: 140) and is 'in inner
8. Nemeskürty explains that Radványi ‘in 1942 signed a contract which took him to Italy, because he was not allowed to realize his favourite plans' in Hungary, 'but he was forced to return to Hungary after the Germans occupied Italy' (1968: 145). This is a rather transparent attempt at representing Radványi, a veteran of the pre-war and wartime Hungarian and Italian industries, as an enemy of the Horthy regime. It is rather doubtful that the Italians would have been interested in hiring a Hungarian opposition figure, given the extremely close political ties between Mussolini's Italy and Horthy's Hungary. More on this in the latter part of this article. 


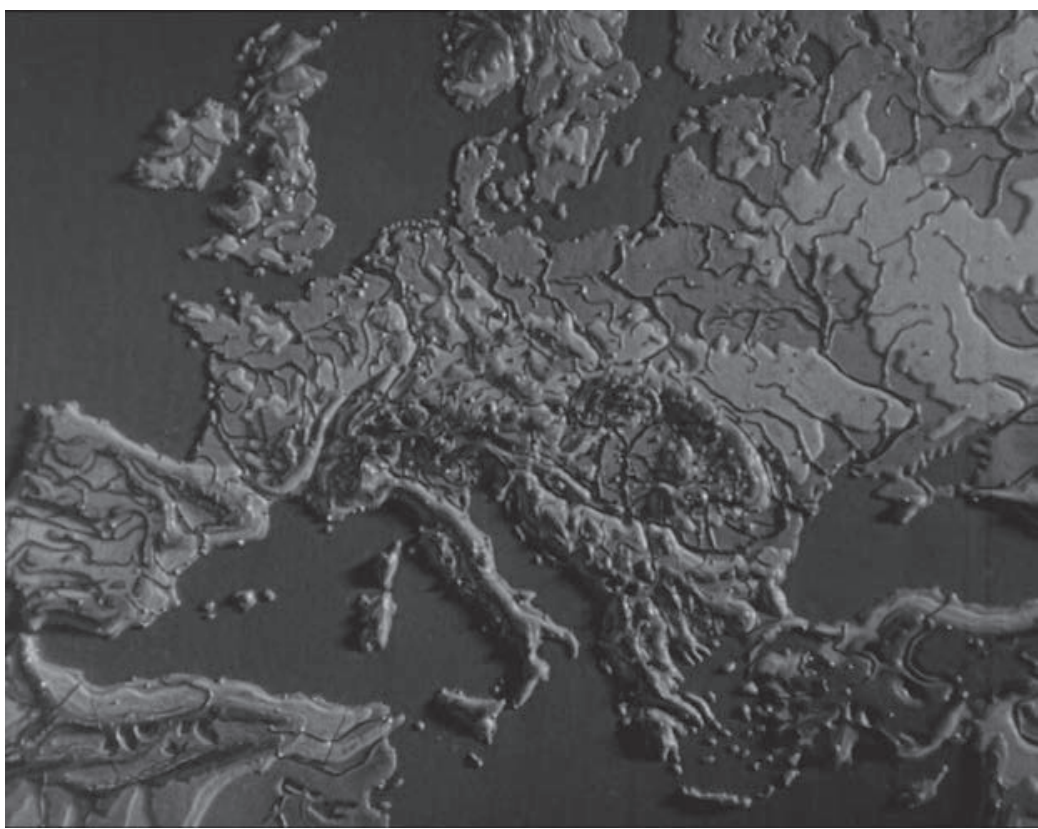

Figure 2: A borderless Europe.

harmony with the post-libēration period' (Nemeskürty 1968: 143). Further, the film's transnational flavour is contradicted by the narrowly Hungarian concern of not so much permeable, but elastic borders and a complete loss of geographical fixity. By this I mean that although a lack of geographical fixity may be a key concept in transnational theory, it is also a very specific trauma that typifies Hungarian history, and has played a hugely significant role in shaping Hungarian national identity. A sharp contradiction can be seen here between the universal relevance asserted by the film and Nemeskürty, and the specifically Hungarian issue of collective (read: national) dislocation. This is an interesting contradiction, one that will be explored throughout the rest of this article.

The film begins with a shot of a relief-printed map of Europe, showing mountain ranges and rivers, but without national borders. A dramatic melody accompanies the shot of the map. This turns out to be the film score's leitmotif. It bookends this opening sequence, and thereby sets it apart from the rest of the film and imbues the exposition with added significance. The second image is a medium shot of a group of children walking across the screen, from left to right, followed by a shot of the map of Europe with the title 'Somewhere in Europe' daubed in white lettering across the frame. A voice- over is heard reiterating the visual information: 'this film takes place somewhere in Europe... somewhere along the river Danube'. The narrator is Artúr Somlay, the actor who plays the old man later on in the film. The decision to have him speak the opening dedication contributes to the film's gradually emerging sense of continuity, of a seemingly seamless transition from the older generation to the youngest generation, leapfrogging the one implicated in the war and Hungary's complicity in the Holocaust. Once the title disappears, the camera closes in on the part of Central Europe that roughly corresponds to the map of pre-Trianon Hungary.
1.

3.

4.

5.

6.

7.

8.

9.

10.

11.

12.

13.

14.

15.

16.

17.

18.

19.

20.

21.

22.

23.

24.

25.

26.

27.

28.

29.

30.

31.

32.

33.

34.

35.

36.

37.

38.

39.

40.

41.

42.

43.

44.

45.

46.

47.

48.

49.

50.

51.

52. 
1.

2.

3.

4.

5.

6.

7.

8.

9.

10.

11.

12.

13.

14.

15.

16.

17.

18.

19.

20.

21.

22.

23.

24.

25.

26.

27.

28.

29.

30.

31.

32.

33.

34.

35.

36.

37.

38.

39.

40.

41.

42.

43.

44.

45.

46.

47.

48.

49.

50.

51.

52.

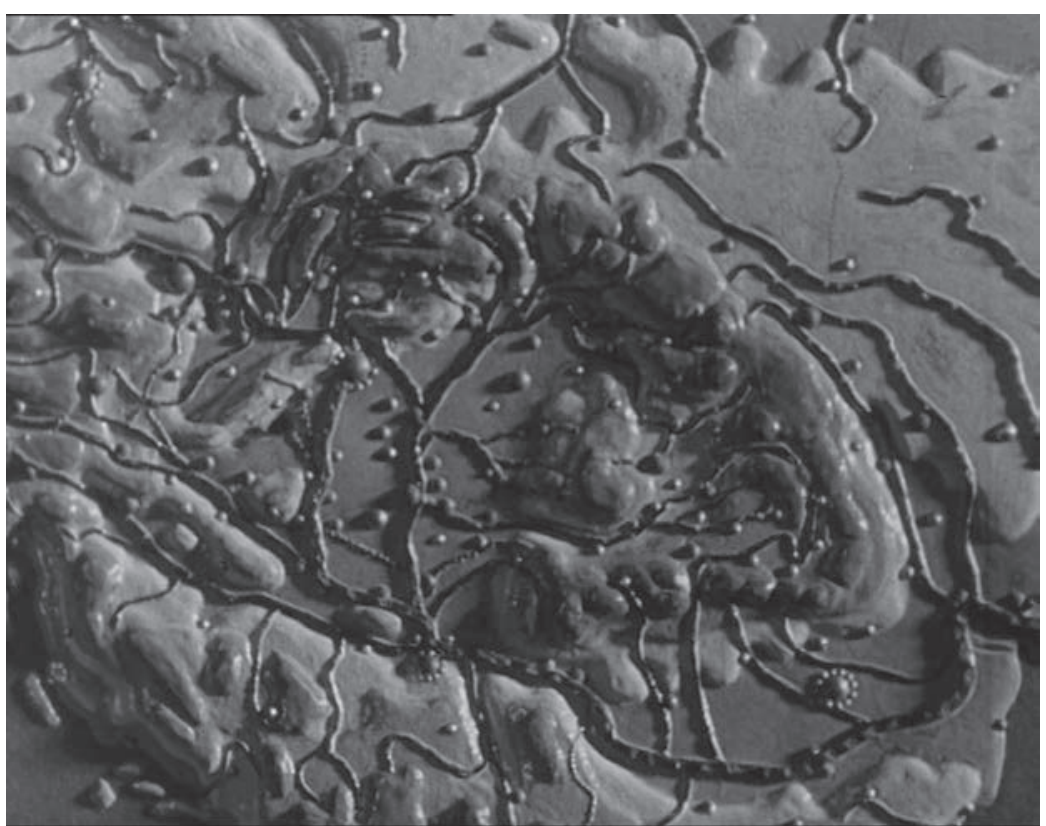

Figure 3: Borderless it may be, but pre-Trianon Hungary is picked out as the camera moves in.

Even as it proclaims its broad European pertinence, and insists on locating the story within a borderless, transnational Europe, the film squarely contradicts its own spirit. The camera fixês and focuses on the very region of the continent whose contested territories had motivated Hungary's entry into the Axis. This conflict between stated purpose and meaning (or compelling reading) characterizes the entire film, and may be explained as a sort of extroverted introspection. By this I mean an interiority, and a preoccupation with the self that is presented in the guise of openness and transnational scope (in the sense of reaching across and beyond the national). First, there is a mistaken belief operating here that the country's narrow domestic political concerns are truly of European pertinence and importance. Second, there is the openly admitted political commitment of most of those involved in the making of the film to a Communist ideology with its strategic aim of a world revolution and international union of proletarian states. Combined with these is the quite literally unmentionable national trauma of the irreversible loss of the territories cut off at Trianon, participation in the war on the side of the Axis, guilt associated with complicity in the implementation of the Nazis' Final Solution programme, and the resultant crisis of identity. As a result, Somewhere in Europe positions itself as a film of universal significance dealing with an issue of universal concern set somewhere in Europe, all the while probing an issue of narrow Hungarian concern within an aesthetic framework that can be said to be typical of the Hungarian film-making tradition.

The shots of the map of Europe are followed by a virtuoso sequence marrying Eisensteinian montage with an aesthetic and moral position reminiscent of neorealism (Brunette 1996: 105). What follows is a fairly detailed description of the sequence of shots that begins here. This is undertaken in quite specific detail in order to give a sense of the sequence, and to justify the 
9. Rossellini's films, especially those of the early 1940s, The White Ship/La Nave bianca (1942) and Man of the Cross/L'Uomo dalla croce (1943), clearly indicate that he studied Eisenstein. See Brunette (1996: 13-16) on this kinship. And in turn, Balázs's The Visible Man had been an influence on the Soviet montage school, and on Vsevolod Pudovkin in particular (Balázs, 1970: 3). contention, in the subsequent analysis, that the film is nourished both by the tradition of neorealism and the Soviet montage school. Although neorealism owes much to the Soviet film-making tradition, especially Eisenstein, whose work is clearly a strong influence on Rossellini in particular, ${ }^{9}$ it would be misleading to attribute the film's aesthetics wholly to the one or the other. It is important to acknowledge the simultaneous impact of neorealism and Soviet montage on Somewhere in Europe precisely because the ability to marry seemingly opposed aesthetic/narrative/ideological systems is, I contend, something that we can see time and again in the Hungarian instance.

The editing follows the principles of Eisensteinian montage, specifically tonal montage (Eisenstein 1957: 75-78). Each frame's composition and content mirrors, emphasizes or clashes with the composition of the previous frame. The first vignette in the opening sequence is a perfect example. The fifth shot of the film is of a young goatherd. The composition is horizontal, closed off by a boulder at one end, and trees at the other end of the frame. The next frame is an aerial view of a flat landscape, with the camera panning right to left, accompanied by the droning noise of a squadron of aircraft, whose point of view the camera has assumed. Already, the set, the framing, the soundtrack and the visual information of the two adjacent frames contrast, emphasize and enhance each other and set up a storytelling based on dialectical progression. As the camera movement approaches its end, plumes of smoke puff up from the ground and the sound of explosions is heard. Here we cut to a medium shot of the child and goats. They start, and the child runs off-screen left to right as dramatic extra-diegetic music is heard. His dart from the frame mirrors the implied movement of the aircraft in the previous shot. Shots of the camera panning right to left and plumes rising as explosions are heard alternate with shots of the child running left to right. A motif that runs through the entire sequence begins in the eleventh shot: we see the feet of the running child. He runs towards the camera, which pans up slightly to give a medium shot of the panicked child. We cut back to the aerial panning shot, moving right to left, with further explosions and plumes of smoke. The next shot is of the boy running towards the camera in a medium shot through smoke, fire and ruins. The camera pans left to right to show what the viewer assumes is the child's bombed-out home. In the next shot, taken from inside the dark interior of the ruined farmhouse, the boy steps through the door and into darkness. The camera dollies in for a close-up of the child's bewildered, tearstreaked face. Throughout, the sequence of shots and the sound editing work together to create a sense of counterpoint: each frame contrasts the ones it is adjacent to, and the music and sound effects are used not to heighten reality, but to impart and complicate meaning.

The close-up of the child fades to goose-stepping jackboots in a waisthigh loose medium shot. This image, which is the recurring visual motif of this sequence, in turn, fades to a close-up of the whistle of a locomotive. This shot dissolves to the script Deutsche Reichsbahn on the sliding door of what must be a cattle wagon. The shadow of a German soldier is clearly recognizable from the distinctive shape of the helmet. There is a cut to an ominous image of the close-up of a barred window on the wagon. The film cuts back to the previous shot of the cattle wagon door as it slams shut. The camera pans to the right and down to settle on the train's wheels as they begin to roll. Extra-diegetic music is heard, imitating the rhythm of a train passing over the points. A series of shots follows. Low-angle medium shots of cattle wagons, each time emblazoned with the name of a different Central European national
1.

2.

3.

4.

5.

6.

7.

8.

9.

10.

11.

12.

13.

14.

15.

16.

17.

18.

19.

20.

21.

22.

23.

24.

25.

26.

27.

28.

29.

30.

31.

32.

33.

34.

35.

36.

37.

38.

39.

40.

41.

42.

43.

44.

45.

46.

47.

48.

49.

50.

51.

52. 
rail carrier used by the Nazis and their accomplices in the deportation of Jews to death camps, alternate with close-ups of spinning wheels. A close-up of a wagon's barred window follows. The bars are prized off. A quick cut back to the wheels of the train interrupt the sequence to heighten the tension. In a close-up of the window, a boy is pushed through the gap and out of the train. In a static shot we see the boy land and roll on the dusty ground. There is a quick cut to a dramatic shot of the shadow of cattle wagons rapidly flashing by, seen against broken rail tracks ending abruptly amongst weeds grown wild. In the medium shot that follows, the boy stands up, and turns to look at the train as it moves into the distance, towards horrors he cannot begin to imagine. There is a cut to a long shot of the train disappearing into the distance. This is followed by a cut back to the child as he puts on his wireframe glasses. The dramatic music transforms into the roll of military drums and we cut to a medium shot of goose stepping soldiers.

It would be misleading to label this a mere economy of storytelling. Meaning emerges out of the productive clash of subsequent shots in the Eisensteinian tradition. This same principle can be seen at work in the sequence where the waxwork statue of Hitler melts in the blaze inside the chamber of horrors of the Budapest fairground. The dimly lit images of waxworks of the victims of torture devices and executioners create an atmosphere of horror reminiscent of German expressionism, a school of film-making that Balázs would have been very familiar with, but the editing of the sequence relies on the montage philosophy of Lev Kuleshov and Eisenstein.

This striking opening sequence of children caught in the barbarity of the war relies on images of trauma that would have been immediately recognizable to contemporary audiences throughout the European Continent. The sequence echoes the film-makers' sentiment, a sentiment the film proudly wears on its sleeves: 'This film is dedicated to the Nameless Child, and to the children who had the same fate on the roads of historical times', the voiceover intones bombastically after the opening credits. The film then seeks community not just with all the peoples of Europe, but also suggests a pertinence to all historical periods across the ages. This can be understood as an attempt to locate the film within a Marxist view of history: the film becomes a milestone in the dialectical progression towards the utopia of world peace and total equality through a series of conflicts. The film implies that this story is one of these. The voice-over continues: 'Our story takes place where the storm of war blew over countries, regions, people and lives... Somewhere in Europe. Somewhere along the Danube'. This is as close as the film comes to specifying the place of action. It is then a film that strives for, if not universal, then European relevance. It hopes to speak to and for all peoples ravaged by the war. But this pan-European relevance is repeatedly undermined. In the sequence of the child seeking shelter from an air raid in the chamber of horrors of a fairground, the vertiginous wooden structure in the background is immediately recognizable as the iconic rollercoaster of the Budapest fairground. It is comparable to Vienna's giant Ferris wheel, the Riesenrad, used to good effect in Carol Reed's post-war classic The Third Man (1949).

The plot of Somewhere in Europe revolves around a group of vagrant children who roam the countryside in search of food and shelter. At one point they flag down a truck. They drag the driver from his cabin, beat him up, take his meagre lunch and leave him for dead in the middle of the road. Later they come across a seemingly uninhabited ruined castle. They find unexpected luxuries within, including a larder groaning with food: bread, sausages, fermented 
cucumber and pickled vegetables. When they realize that an elderly man lives alone in such enviable comfort, they take him prisoner. They taunt him, while devastating his food store. Slowly, however, an uneasy alliance develops between the old man and the children. The old man slowly teaches them selfcontrol, respect for each other, and the value of forward planning. He oversees their slow transformation from dangerous gang into viable community. When the local villagers, despairing of the constant raids by this and other feral child gangs on their fields, granaries and larders besiege the castle, the children, under the command of the old man successfully defend their new home. They become a tightly knit group, a new community that despite the death of one of its members now holds a great promise for the future.

With its focus on societal tensions, the devastation of the war and its bleak legacy of poverty, and on the figure of the orphaned child full of hope but also hopeless, the film brings to mind the narratives of Italian neorealist cinema. Just as in Sciuscia/Shoeshine (Vittorio de Sica, 1946) or Germania anno zero (Roberto Roessellini, 1948), in Somewhere in Europe, too, the war continues to take its victims long after it officially ends. The children are caught up in a conflict that is not of their own making. They emulate the previous generation to their sorrow. Just as in Shoeshine, in Somewhere in Europe the children's instinct to resolve conflict through violence is a grim legacy of the recent past. Having just taken possession of the old man's castle, one of the gang cries out in a wistful whine that sends shivers down the spine: 'boys, I beg you, let's hang him!'. Neorealist films usually end on a note of uncertainty or a fatalistic step into the unknown. For instance Bruno and his father walk off into the distance, towards certain hardship and continued struggle for survival in The Bicycle Thief (De Sica, 1948). Umberto, too, shuffles off into the distance in an overexposed frame at the end of Umberto D (De Sica, 1950). Somewhere

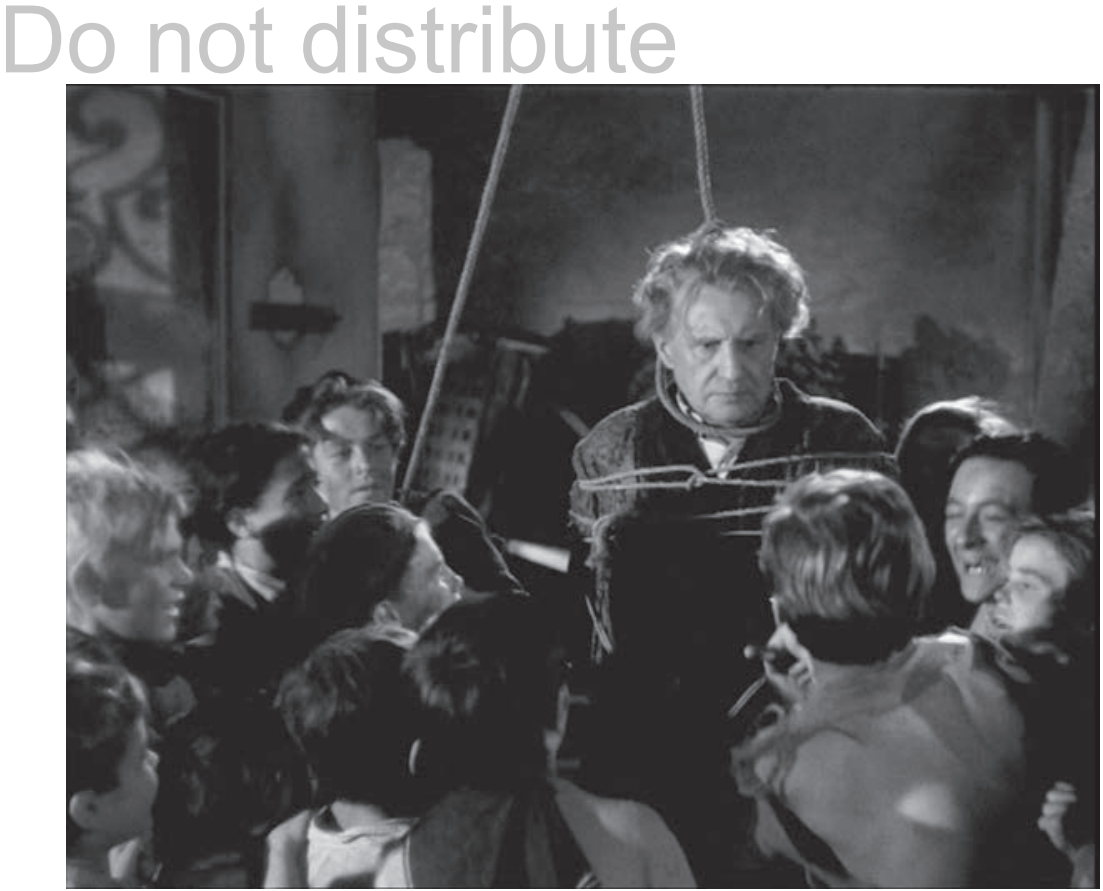

Figure 4: The boys come close to hanging their reluctant host.
1. 2. 3. 4. 5. 6. 7. 8. 9. 10. 11. 12. 13. 14. 15. 16. 17. 18. 19. 20. 21. 22. 23. 24. 25. 26. 27. 28. 29. 30. 31. 32. 33. 34. 35. 36. 37. 38. 39. 40. 41. 42. 43. 44. 45. 46. 47. 48. 49. 50. 51. 52. 
in Europe, by comparison, ends on a far more upbeat note, with the old man and the children looking forward towards a brighter future, showing a clear kinship with Soviet cinema and its socialist realist ideal of 'reality as it ought to be', rather than reality as it really is (Taylor 2008: 157).

To recap briefly, Somewhere in Europe is a film that combines aspects of Italian neorealism with Soviet socialist realist cinema and the Soviet montage school (to which neorealism is, itself, indebted). Its use of the figure of the child to talk about new beginnings under the shadow of old wrongs and the reliance on location-shooting indicate its debt to Italian neorealism. The idealistic ending, where the disadvantaged youth overcome the obstacles presented by entrenched opposition from those in a position of power, the reliance on the montage technique and the strong ideological message ally it with prewar Soviet cinema. The atmosphere and mise-en-scène of the sequence where the small boy hides out in the dungeon of horrors and the waxwork of Hitler melts in a chilling metaphor for the disintegration of the Third Reich brings to mind the German expressionist tradition, with its reliance on shadow-play, evocations of the monstrous and unsettling settings.

Before I continue to explore the film's mixture of different styles and influences, I must pause very briefly to consider the figurine of Hitler, and how it may have been possible for such an effigy to be on show in the dungeon of horrors while Budapest was still being bombed. The answer is simple: it is impossible. Budapest remained under Nazi control until the end of the siege. There was no 'Budapest Open City', nor an agreement to spare the city's population or architectural heritage. A bitter battle from street to street ensured maximum devastation, and there was no transitional period in which Hungarians, free of Hitler's rule, could have designed, made and displayed an effigy of the dictator in the fairground.

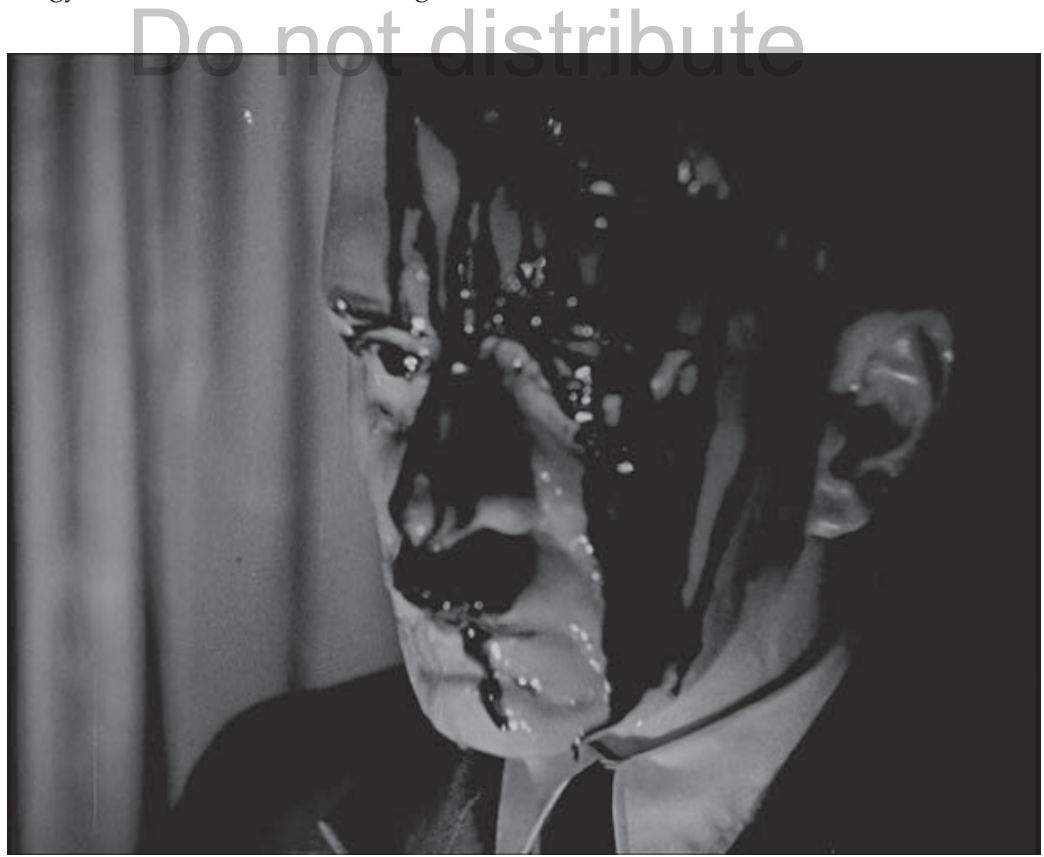

Figure 5: History re-imagined: a waxwork of Hitler melts in the dungeon of horrors of the Budapest fairground Vidámpark. 
10. Radványi was born Géza Grosschmid into a German minority family in what was then Kassa, Hungary in 1907. In some ways, he is a stereotypical Hungarian of the period. Hungarian by nationality, German by extraction, he saw his birthplace change nationalities three times in his lifetime. Just seven years after his death, it would change countries again, when Slovakia split from Czechoslovakia in 1993

11. According to his IMDb filmography (Internet Movie Database): http://www.imdb.com/ name/nmo373816/, accessed 8 March 2012.
This 'slight' historical inaccuracy can be ascribed to wishful thinking, or, more precisely to the Soviet socialist realist principle. Hungary had remained within the Axis until the bitter end, the country's Arrow Cross leadership were fanatical devotees of Hitler and strained every sinew to implement the Final Solution programme even as they knew the war would be lost. As Braham has chillingly concluded: aware that the military conflict against the Allies was lost, the Nazis and their Hungarian accomplices sought to win the other war, waged against the Jews of Europe (2000: 201). A more palatable version of history is the one implied by the film: even before Liberation, Hungarians had begun to shake loose the shackles of an alliance with Hitler and his murderous regime. The unlikely appearance of Hitler amongst other horror waxworks can then be attributed to a desire to project a less damning version of events in the spirit of the socialist realist ideal of representing reality not as it is, but as it ought to be.

To return to the film's mishmash of cinematic styles, from Italian neorealism to Soviet socialist realism via montage and German expressionism, the question inevitably presents itself: to what extent is Nemeskürty right in declaring this one of a handful of films that represent a new impetus and a new trend in Hungarian cinema? Throughout the inter-war years, the Hungarian film industry depended on an exchange of talent and indeed genres with the country's ally Italy, and later Germany. The Hungarian matinee idol Pál Jávor starred in Italian films in the 1930s and 1940s. The director of Somewhere in Europe, Radványi, ${ }^{10}$ had directed a film in Italy, Inferno giallo (1942), starring his wife, Mária Tasnádi Fekete. As I mentioned earlier, Balázs himself had written films for G. W. Pabst, and Leni Riefenstahl (although later the Nazis removed his credit for Das blaue Licht, which Riefenstahl directed in 1932). Just as neorealism itself grew out of the Fascist film industry, and can be traced back to pre-war beginnings (from the films of Rossellini to the scripts of neorealism's chief thinker Cesare Zavattini), so did this 'new' Hungarian cinema grow out of existing trends and attitudes prevalent in the Hungarian industry. Béla Balázs may have set up a new journal and begun teaching a new audience, as well as training new creative teams, but he took his inspiration from Soviet revolutionary cinema.

Nemeskürty's phrase, 'new audience' (1968: 139), is an extremely revealing one. It forms part of a strategy of reinventing post-1945 Hungary as a wholly new nation, one untainted by complicity in the war or the events that had led to it. In the official state-sanctioned discourse of Nemeskürty's text, the nation's imagined awakening to a new and ideologically correct (read: Socialist) consciousness constituted a clean break with the past. The insidious effect of this imaginary break with the wartime self of the nation can be seen in Germany, too, where the former East Germany is now a hotbed of neo-Nazism. Not because of the ease with which former Nazis transformed into keen Communists, but because the past remained wholly unexcavated and unacknowledged.

Writing in 1968, Nemeskürty wrongly applauds the personnel associated with this film for bringing a breath of fresh air to post-war Hungarian cinema. 'Untalented craftsmen who had been active during the war years disappeared', Nemeskürty writes (1968), dismissing in a few words any possibility of continuity between the post-war present and the wartime past. In fact, however, Radványi, Balázs, the composer Dénes Buday, the cinematographer Barnabás Hegyi, and the editor Félix Máriássy were all experienced film industry figures who had cut their teeth in the 1930s and 1940s. Hegyi had shot a staggering 44 films in 1940-1944. ${ }^{11}$ Somlay, the actor who plays the old man in the film, had been a popular character actor in the inter-war years, and remained active
1.

2.

3.

4.

5.

6.

7.

8.

9.

10.

11.

12.

13.

14.

15.

16.

17.

18.

19.

20.

21.

22.

23.

24.

25.

26.

27.

28.

29.

30.

31.

32.

33.

34.

35.

36.

37.

38.

39.

40.

41.

42.

43.

44.

45.

46.

47.

48.

49.

50.

51.

52. 
in the film industry throughout the war years. Even Miklós Gábor had made his debut in Hungarian films in 1941, although his career did not take off until after the war. He was already nearly 30 when he appeared in Somewhere in Europe in the role of Hosszú, the leader of the gang. That is not to say that they were all necessarily implicated in war crimes, or that they collaborated in any meaningful sense of the word..$^{12}$ It certainly indicates, however, that they were not newcomers to the profession, or the domestic industry in 1947.

Even if we buy into Nemeskürty's revisionist account of a new audience and new film-makers, his reading of the film as one displaying the 'sweeping impetus of starting something new' and representing a 'really revolutionary confrontation with the past' (1968: 140) cannot pass muster. Incidentally, this reading, inspired by the need to establish a clean break between Hungary's past as an Axis ally and its 1960s present as part of the great Communist world revolution, is the definitive reading of the film in the Hungarian context. Even Kenez, an otherwise astute historian of Soviet Stalinist cinema, offers a strikingly similar verdict to Nemeskürty (2006: 245-46). Just as that other paragon of Hungarian cinema, Szöts's Ének a búzamezökröl/Song of the Cornfields ${ }^{13}$ (1947) grew out of the German Heimat film tradition, so Radványi's Somewhere in Europe emerged from the productive intermingling of a wide variety of styles and traditions and cannot be labelled as new either in the specifically Hungarian or the transnational context.

Once more, however, the film's transnational resonances must be called into question. Having just established the film's roots in the broader European film-making culture, I now seek to demonstrate Somewhere in Europe's exclusively Hungarian pertinence, its opening voice-over and obvious debts to Soviet socialist realism, the montage school and Italian neorealism notwithstanding. The films of Italian neorealism chart the struggles of building a new nation on the urban ruins of the previous regime. The protagonists of Italian neorealism succeed or fail amid the ruins of Mussolini's Italy, itself just a layer on top of the Renaissance city states, Imperial Rome and the Republic before them. Soviet revolutionary cinema charts the rapid urban modernization of the first decade of Communist rule and the construction of a bright new future on the ruins of Tsarist Russia (see Fridrikh Ermler's staggering Fragment of Empire/Oblomok imperii, 1929), or it paints heroic tableaus of agricultural mechanization and rural modernization (see Dovzhenko's Earth/Zemlya, 1930, or Eisenstein's The Old and the New/Staroye i novoye, 1929). Soviet socialist realist films give account of the acquisition of socialist revolutionary consciousness in previously apolitical members of the oppressed classes, often depicting the battle for the hearts and minds of the peasantry (see Georgi and Sergei Vasilyev's Chapayev, 1935). Somewhere in Europe cannot be said truly to follow any of these traditions. In Radványi's film the gang of children leave the urban devastation and withdraw to the countryside. There they reconnect with the values of the past. The past, including culture and tradition, is embodied by the hermit-like composer and conductor of global fame, who has sat out the previous conflict, and is well set up to sit out the next one. Under his leadership, the gang are forged into a cohesive community by the death of one of their own. This sense of community finds its expression in their new-found respect for the old man (Hungarian cultural values), the soil (Hungarian geographical values), the ruined castle (Hungary's history of glorious agonies) and their future lived in joyful isolation. This triumphant and absurdly optimistic turn inward, away from the world, yet calling for global attention while doing so, is what I referred to as extroverted introspection earlier in this article.
12. Whether they did or not is for historians to decide. Much of this work remains to be done in Hungary. Under the Communist regime that began in 1948, Hungary's role in the war became a taboo subject. In the official version of history, the war became something that happened to Hungary, with Hungarians playing the role of victim, peaceful resister and occasional anti-Fascist martyr.

13. The film was financed by the moderate smallholders' party FKgP, the party with the broadest popular support, and therefore greatest threat to Communist ambitions. They would be outmanoeuvred and finally cheated out of election victory by the MKP in the rigged elections of 1947 (2006: 259-88). 
The film's mishmash of cinematic styles, its simultaneous reliance on the aesthetics of the Soviet montage school and socialist realism with the moral posturing of Italian neorealism and the soil-centred ideology of the Heimat tradition, reflects a double crisis of identity. One is the crisis of a film industry with a long history but no truly indigenous tradition. Hungarian cinema's first decades, indeed, one could argue the entirety of Hungarian cinema, can be described in relation to the predominant foreign influence of the time. The films of the 1910s sought to satisfy foreign audiences' demand for local colour, and, starting with Son of the Pusta/Sárga csikó (Félix Vanyi, 1913) plundered Hungarian folklore and the folklore-steeped works of népies or countryside novelists of the late nineteenth and early twentieth centuries. The reprisals that followed the Hungarian Soviet revolution of 1919 saw the first wave of a crippling brain drain. Kertész Mihály (Michael Curtiz), the Korda brothers, Béla Lugosi, Oscar Beregi and many others fled to Vienna, Berlin and further West. Protectionist measures in the 1920s helped boost output. Frequent exchanges with the Italian and German film industries contributed to the emergence of a Hungarian film-making tradition that can be seen to emulate the genres prevalent in the Italian industry of the inter-war period. Fluffy comedies set amongst the upper classes, comic and tragic romances and moody melodramas were most common. The future émigré Steve Sekely's Hyppolit a lakáj/ Hyppolit the Butler (1931) and Halálos tavasz/Deadly Spring (László Kalmár, 1939) starring the matinee idol Pál Jávor typify the period. The late 1930s and the war years saw the dominance of the German Heimat film tradition, with its focus on peace and unity rooted in the ordered simplicity of rural life overseen by benevolent aristocratš, conscientious estate managers and sometimes disrupted by alien-hearted traitors, cosmopolitans (Hungary's

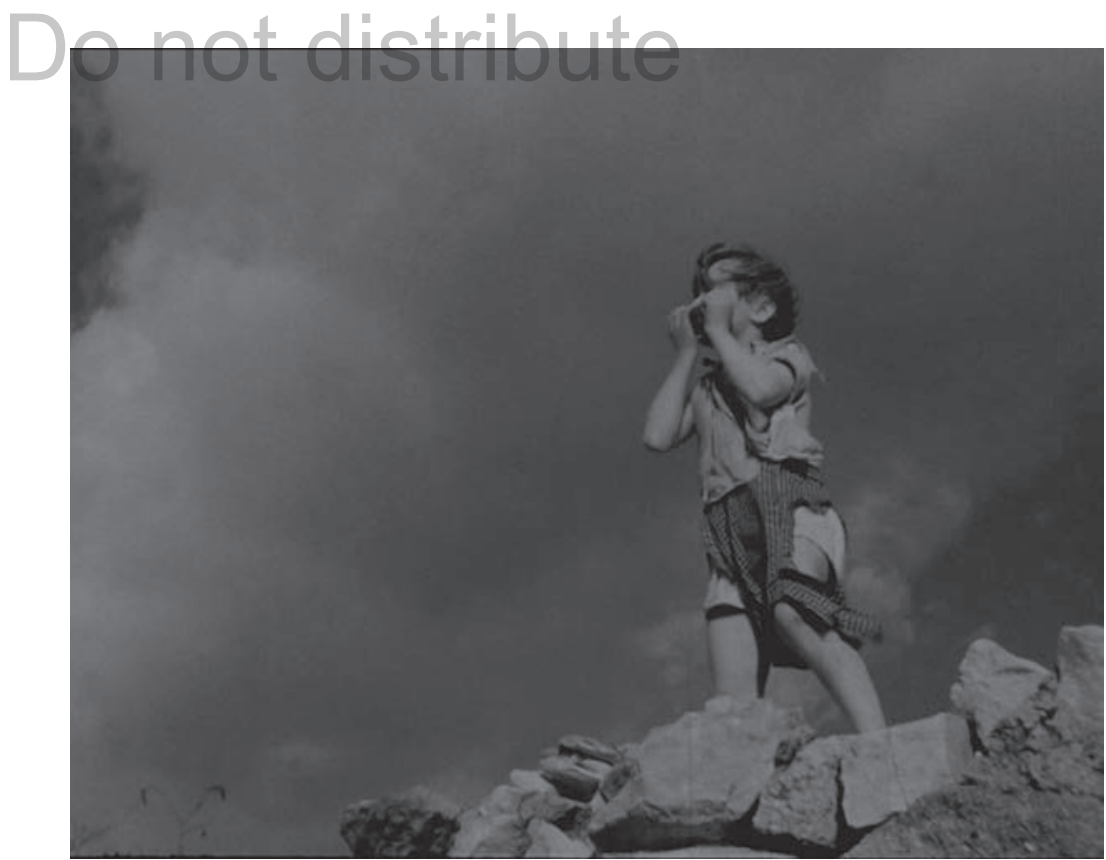

1. 2. 3. 4. 5. 6. 7.

Figure 6: The moment of martyrdom is also the point of birth of a community united by a shared sense of victimhood. 
favoured codeword for 'Jew' then and now) and scheming parvenus. The films of the actor Antal Páger (Szeretó fia, Péter/Your loving son, Péter and Dr Kovács Istoán, both Viktor Bánky, 1942) are the prime examples of the films of the period. This trend of transnational genre-swapping would continue in the 1950s with Stalinist production films and French New Wave-inspired semi-autobiographical auteur films in the 'soft dictatorship' of the 1960s.

The other crisis reflected in Somewhere in Europe's mixture of styles is a crisis of identity brought about by the reinstatement of the Trianon borders at the end of the war. Allied occupation and the realization that the restoration of what is referred to as 'historical Hungary' will likely never be achieved inevitably resulted in a crisis of national identity. It is this crisis of a country, whose actual geographical location would forever remain in conflict with its collective self-image, that can be apprehended in the narrative of vagrant youths roaming the landscape in search of food and shelter. Played out onscreen is the national trauma: lost, bewildered, self-avowedly innocent victims of the recent European devastation wander the land in search of a place they can call home.

\section{CONCLUSION}

This geographical dislocation continues to characterize the country: Hungary to this day remains a country that imagines its national community to stretch far beyond its actual borders. It sees itself as a perpetual victim of global upheavals, and cannot define itself with any more accuracy than a country 'somewhere in Europe... somewhere along the Danube'. As the voice-over continues the camera slowly moves in on a very specific part of the map of Europe: Hungary. The lack of borders on the title sequence's map of Europe then speaks not of a genuinely cross-border experience of trauma, but of the very specific trauma of a country without borders, a country without a solid identity and a country with a very sketchy idea about its own future. Rather than a truly revolutionary confrontation with the past, as read by Nemeskürty, ${ }^{14}$ this is a film that gives evidence of a lack of identity born as much out of the redrawing of the nation's borders as of the selective memory of its people.

Nemeskürty concludes his chapter devoted to the post-war liberation period of 1945-1948 by revisiting Somewhere in Europe. Without any indication of an awareness of the contradiction with his opening remarks about the 'newness' of Radványi's film he enthuses: 'the noise and battle-cries of the children defending their castle could be heard all over Europe. A message was addressed to mankind. The best men of Hungarian films in the time before Liberation took up work again' (Nemeskürty 1968: 145). In the space of just a few pages devoted to the period, Nemeskürty achieves the remarkable feat of declaring Radványi an artist with the sweeping impetus of something new as well as a returning veteran of the inter-war tradition, a truly revolutionary synthesis of the old and the new. Just like the film and the critic, the country too is confused and deluded, the victim of a national crisis of identity.

\section{REFERENCES}

Balázs, B. (1970), Theory of the Film: Character and Growth of a New Art, New York: Dover Publications.

Braham, R. L. (2000), The Politics of Genocide: the Holocaust in Hungary, Detroit: Wayne State University Press.
14. Admittedly, Nemeskürty was probably under pressure to justify the MKP's investment in the film in 1947. 
(2001), Studies on the Holocaust, Selected Writings, vol. 2, New York: 1.

Columbia University Press.

Brunette, P. (1996), Roberto Rossellini, Berkeley, Los Angeles and London: University of California Press.

Cunningham, J. (2004), Hungarian Cinema: From Coffee House to Multiplex, London: Wallflower Press.

Eisenstein, S. M. (1957), Film Form the Film Sense (ed. and trans. J. Leyda), New York: Meridian Books.

Kenez, P. (2006), Hungary from the Nazis to the Soviets, Cambridge: Cambridge University Press.

Nemeskürty, I. (1968), Word and Image (trans. Zs. Horn), Budapest: Corvina Press.

Parvulescu, C. (2012), 'The continent in ruins and its redeeming orphans: Géza Radványi and Béla Balázs's Somewhere in Europe and the rebuilding of the post-war polis', Central Europe, 10:1, pp. 55-76.

Taylor, R. (2008), The Politics of the Soviet Cinema, 1917-1929, Cambridge: Cambridge University Press.

\section{SUGGESTED CITATION}

Gergely, G. (2012), 'Somewhere in Europe (1947): Locating Hungary within a shifting geopolitical landscape', Studies in Eastern European Cinema 3: 2, pp. 133-150, doi: 10.1386/seec.3.2.133_1

\section{CONTRIBUTOR DETAILS}

Gábor Gergely completed his Ph.D. at the University of Exeter in 2011. His book on the émigré actors Peter Lorre, Béla Lugosi and Conrad Veidt, Foreign Devils is forthcoming with Peter Lang. He is taking up a Leverhulme Early Career Fellowship at the University of Manchester in September. His research project investigates anti-Semitism and national identity in Hungarian sound film up to 1944 .

Contact: University of Exeter. The Queen's Building, The Queen's Drive, Exeter, EX4 4QH.

E-mail: gg214@exeter.ac.uk

Gábor Gergely has asserted their right under the Copyright, Designs and Patents Act, 1988, to be identified as the author of this work in the format that was submitted to Intellect Ltd. 